\title{
Social Media And Its Effects On Muslim Students: The Case Of Nasarawa State University, Keffi, Nigeria
}

\author{
Atiku Garba Yahaya,a,* Muhammad Maga Sule,b \\ a Professor, Department of Islamic Studies, Usmanu Danfodiyo University, Sokoto. \\ b Department of Islamic Studies, Usmanu Danfodiyo University, Sokoto. \\ *Corresponding author: agyabya@yahoo.com
}

\section{Article history}

Received: 2017-07-13

\begin{abstract}
This research centered on the effects of social media on Muslim students in Nasarawa State University, Keffi. The purpose of this is to examine how Muslim students make use of the social media and the effects of these social media sites on them, the level of Muslim students' awareness of social media, how to properly make use of the social media sites for the propagation of Islam. The research used quantitative methodology. Questionnaire was used as instrument for data collection. Similarly, textbooks, journals, as well as internet sources were used for the research. The research found that social media as a tool has created a new social dimension in the lives of Muslim students. Social media has developed and increased their levels of religious, educational and social awareness. It is argued in the research that, social media has provided an avenue for getting information in many aspects of everyday life, making one to become more knowledgeable which is beneficial especially for Muslim students. The research found that most of the Muslim students surveyed were aware of the positive and negative effects of social media sites and were also conversant with the social media sites that propagate Islam. Some of the social media sites utilized by Muslim students are Facebook, WhatsApp, Ummaland, Masjidway, Nahnu Muslim and Muslim Social to mention but a few.
\end{abstract}

Keywords: Social Media, Positive, Negative Effects and Muslim Students. 


\subsection{INTRODUCTION}

The proliferation of social networking sites has exploded in recent years, with an especially significant increase in membership levels as seen in the case of Facebook and other social media platforms. It is obviously important to try and understand the means of communicating through social media. Hence social media are interactive platforms that allow users to interact with each other as well as send and receive content from and to each other generally by means of the internet. They are media that allow users to meet online via the internet, communicate in social forum like Facebook, twitter and other chat sites, where users generally socialise by sharing news, photos or ideas and thoughts, or respond to issues and other contents with people. Common examples of social media are the popular networking sites like Facebook, MySpace, YouTube, Flicker, Bebo, Wechat, Badoo and Google+. Social media are technologies that facilitate social interaction, make possible collaboration, and enable deliberation by stakeholders across boundaries, time and space. These technologies include blogs, wikis, media (audio, photo, video, text) sharing tools, networking platforms (including Facebook), and virtual worlds (Sanusi, Gambo and HadiAshara, 2014).

Social Media are recent phenomena and from their inception, Social Networks have attracted many University students as well as their lecturers. These Social Media may be centered at sharing cultural views and religious beliefs (Gehad, Mahdi and Azizah, 2012). The Internet provides a space and medium within which Muslims can share the relationship between their religious identity and their social and political affiliation. Many of these Social Media like Facebook, provide platform for Muslim Students in sharing permissible components of data with their fellow Muslims friend and relatives (Gehad, Mahdi and Azizah, 2012).

Social media is a medium that can allow students to engage in discussion that clarifies, expands and provides autonomy over content, without the added challenge and immediacy of comprehension. The ever-expanding use of social media, especially mobile media devices, enables potential publics to be engaged with organizations and businesses almost continually, and decision makers within these organizations must exercise behavioural soft skills that connect at the right level (Robert, 2013).

The rise of social media sites as another platform on the internet has gained popularity over the last decade. The sites have attracted millions of users worldwide. Due to this fact, many people are changing the outlets where they search for news, information, business and entertainment. These social media sites let those who use them create personal profiles, while connecting with other users of the sites. Users can upload photographs and post what they are doing at any given time (Pempek, Yevdokiya and Calvert, 2009). The social media by their nature have the capabilities of educating and entertaining the audience. Above all, they possess an outreaching influence which conventional media lack. This potential is most likely the most unstoppable power of the social media.

Ahmed (2011) study concluded that there is a significant difference of use of social networking sites between male and female students. Male students are more inclined towards use of these sites than female students. But study did not find any significant effect on area of study, educational level, study year, on the extent of social networking site usage. Studying habits of the students were found to be significantly affected by the time spend on leisure activities, time spent on Internet, time spent on using social networking site and basic purpose of using social networking site while there was not any significant effect of leisure activities and purpose of 
using internet on studying habits of the student users. On the findings of the study, there was a significant effect of time spent on social networking site usage, time spent in internet and basic purpose of internet usage on academic performance of the students. Hence, internet and social networking site usage significantly affect the studying habits of the students and eventually their academic performance.

This study provides a preliminary analysis of the effects of social media usage by students. Social media affect the academic performance of youth and social network sites badly affect the GPA of students in examination. A researcher points out those Facebook users give less time to studies as compare to nonusers do and later on has lower GPA in their examination (Paul \& Karpinski, 2009). Extensive usage of internet and the particularly use of Facebook by students with extraverted personalities escort towards the poor academic performance. Students' cognitive absorption with Facebook is synchronized only by their strength of will and personality qualities, which determine how much time they spend on Facebook (Sana, Moez and Esmail, 2011). Likewise, (Khan, 2009) found that Facebook users had poor performance in exams. (Englander et al., 2010) proclaimed that internet usage is negatively associated with academic performance of student users and destructive impact of internet usage is far more momentous than its advantages. Internet addiction has come forth as a result of striking boost in internet usage over the past few decades. (Nalwa and Anand, 2003) proposed that addicted users prefer using internet setting back their personal and professional responsibilities and this ultimately leads to poor academic performance.

Facebook become hurdles between students and his academic tasks (for example multitasking). Increase number of studies shows that today's students spend their time in watching television, type out instant messaging on mobile, or engage in social networks sites such as Facebook and at a time they doing academic tasks like studying, schoolwork and home work (Junco, 2012). Abubakar, (2011) posits that social media, which include blogs (political Blog), networks (Facebook, Twitter, etc.), video sharing (YouTube) audio sharing (Podcast), mobile sites (2go etc.), image or picture sharing (flicker), etc. have the capacity of boosting participation because of their open, conversational nature, connectedness and textual and audio-visual characteristic appeals.

A study conducted in 2013 to find out students' use of social media revealed that students view social media for the purposes of leisurely entertainment, to watch films, to expose themselves to phonography, discuss serious national issues like politics, economy, and religious matters on the new media. (Greg, Chika and Obiorah, 2013). Nigeria, a country with population of 167 million people (Census 2006), 115 million mobile telephone subscribers and 56 million internet users, has been described as the biggest internet and mobile market (NCC, 2013). Today in Nigeria there are over 1000 social media networking sites, which include social, educational, entertainment and gossip, etc. One common feature of most of these sites is that their names are usually associated with a tag name Naija or Nigeria.

The mass appeal of social media on the internet could be a cause for concern, particularly considering the gradually increasing amount of time youths spend online. In Nigeria, undergraduates spend more time on Facebook, Twitter and other social media sites through smartphones that are now in abundance among them and most of them cannot go for two-three hours without checking and updating their profiles on these social networks even at the detriment of other activities such as educational and career pursuit. (Idankwo, 2011) 
Muhammad, Ghani, Zumrah, Roslizawati, Fazrul and Zainol (2013) expounded in their work "Facebook as Social Media Tool among Muslim Youths in Malaysia" discussed that, the existence of social media has created a more independent sphere among the citizens. At the press of a button or a touch of a finger on the screen, users are able to channel out opinions to get chains and chains of feedback globally for that matter. Social networking sites such as MySpace, Facebook, YouTube, Twitter etc., have allowed users to chat, to exchange information and also to be persuasive unlike radio and television.

In the past, seeking knowledge about Islam was mainly restricted to the Masjids, educational institutions, and learning from imams and sheikhs. These traditional learning opportunities remain intact. However, now Muslims are also able to learn, question, teach, and network through social media sites. There are more avenues through which to learn about Islam. The Internet has given the public access to all kinds of information and made Islamic literature so much more accessible. On YouTube, for example, you can listen to a lecture in any language you want and whenever you want. Blogging sites such Muslim Matters.org and SuhaibWebb.com have become extremely popular with both Muslims and non-Muslims as a way to gain information and learn about Islam (Salman, nd). Twitter and Facebook, though, have undoubtedly been the two networking sites with the most active Muslim users. These sites have allowed us to connect with Imams and sheiks, political leaders, scholars, and journalists. Furthermore, they have enabled us, at a moment's notice, to share news and information that matter to us.

According to Sanusi, Gambo and HadiAshara (2014) the numerous problems of social media usage have recently been the major focus of attention worldwide. Issues of fraud, identity thefts, pornography and countless other negative influences associated with social networking in general have been a cause of concern for scholars and authorities worldwide. There are increasing concerns on the use of social media for internet crimes ranging from hacking to recruitment for terrorism. The social media has accordingly come to be seen in many countries including Nigeria as a source of bad influence on the youth, particularly students.

A growing number of Nigerian scholars agree that addiction to social media sites are potentially a disruptive technology to students' academic work in higher education. Among them is Oluwatoyin (2011) who surveyed 1,860 Facebook users from the Lagos State University and found that most of the students could not get cumulative grade point average (CGPA) above 3.50 because they've spent large part of their time on social media than on their homework and study time which could contribute to higher grade. Oluwatoyin's findings is further supported by Ajewole and Fasola (2011) whose study of 884 students from eight higher institutions in Oyo State showed that majority of them spend more time on social media at the detriment of their studies.

This view is however rejected by some researchers who acknowledge that social media sites not only re-engage learners with their studies but also enhance their academic performance. For instance, Onyeka, Sajoh \& Bulus (2013) argue that the frequent use of social media sites has no negative effect on the students' studies. In the same vein, Ogedebe, Emmanuel \& Musa (2012) posited that Facebook usage does not have adverse effect on the academic work of students in the Universities. By and large, this study among other things is set to methodically examine why the students in Nasarawa State University Keffi, Nigeria make use of the social media. The reason for such academic inquiry is to unravel some of the effects of social media on Muslim student's and purposes which students use the new media to achieve. 


\subsection{METHODOLOGY}

For a systematic investigation, data gathering, appropriate analysis and interpretation, the following research technique was employed. The use survey research technique was employed. This was considered suitable for this research because according to Busha, (1979) it is a method which allows investigator to gather information about target population without undertaking a complete enumeration which no doubt will enable one to generalize, as well as save time and money without sacrificing efficiency, accuracy and information adequacy in the research process.

\subsection{Data Collection Procedures}

The data for this study were gathered by means of a survey questionnaire administered to 445 Muslims students from the different faculties in the university. The survey instructed students to provide feedback about their experiences using social media.

\subsection{Data Presentation and Discussion of Findings}

The cross-sectional survey has administered 445 questionnaires but 400 questionnaires were retrieved. The retrieved questionnaires were collated; analysis was performed using the SPSS statistical software.

Table 1: Distribution of Questionnaire to Faculties

\begin{tabular}{|c|c|c|c|c|}
\hline Faculty of Respondents & $\begin{array}{c}\text { Total } \\
\text { Questionnaire } \\
\text { Administered }\end{array}$ & Percentage (\%) & $\begin{array}{c}\text { Total Questionnaires } \\
\text { Returned }\end{array}$ & Percentage $(\%)$ \\
\hline Administration & 80 & 17.97 & 73 & 18.25 \\
\hline Agriculture & 30 & 6.75 & 29 & 7.25 \\
\hline Arts & 75 & 16.85 & 64 & 16.00 \\
\hline Education & 80 & 17.97 & 68 & 17.00 \\
\hline Law & 30 & 6.75 & 70 & 6.75 \\
\hline Natural and Applied Sciences & 75 & 16.85 & 69 & 17.50 \\
\hline Social Sciences & 75 & 16.85 & 400 & 17.25 \\
\hline Total & 445 & 100 & & 100 \\
\hline
\end{tabular}

Source: Field Survey 2016.

The above table shows the number questionnaires distribution and returned by students of the different faculties of the Nasarawa State University, Keffi. The highest number of questionnaires was administered to the faculties of Administration and Education, while the lowest number of questionnaires were administered to the faculties of Agriculture and Law $6.75 \%$. This implies that there was significant percentage of return rate.

Table 2: Age of Respondents

\begin{tabular}{|c|c|c|}
\hline Age & Frequency & Percentage $(\%)$ \\
\hline $18-25$ & 106 & 26.50 \\
\hline $26-31$ & 165 & 41.25 \\
\hline $32-37$ & 105 & 26.25 \\
\hline 38 and Above & 24 & 6.00 \\
\hline Total & 400 & 100 \\
\hline
\end{tabular}

Source: Field Survey 2016.

Page | 34 
The table above shows that the ages of the majority of the Muslim students of Nasarawa State University range from $26-31$ which is (165) or $41.25 \%$ while the lowest is (24) or $6.00 \%$ from 38 and above. This implies that majority of the respondents or sampled students are in their youthful age hence fall in the age bracket of internet savvy.

Table 3: Sex of Respondents

\begin{tabular}{|c|c|c|}
\hline Sex & Frequency & Percentage (\%) \\
\hline Male & 248 & 62.00 \\
\hline Female & 152 & 38.00 \\
\hline Total & 400 & 100 \\
\hline
\end{tabular}

Source: Field Survey 2016.

Table above shows that (248) or $62.00 \%$ of respondents were males while (152) or $38.00 \%$ were females. This implies that the majority of students in Nasarawa State University sampled were male and the lowest were females with $38.00 \%$. This shows that most of the respondents that utilized social media in the Nasarawa State University Keffi are male.

Table 4: Level of Study of Respondents

\begin{tabular}{|c|c|c|}
\hline Level of Study & Frequency & Percentage $(\%)$ \\
\hline 100 Level & 97 & 24.25 \\
\hline 200 Level & 109 & 27.25 \\
\hline 300 Level & 94 & 23.50 \\
\hline 400 Level & 85 & 21.25 \\
\hline Postgraduate & 15 & 3.75 \\
\hline Total & 400 & 100 \\
\hline
\end{tabular}

Source: Field Survey 2016.

The above table shows that the highest number of respondents (109) or $24.25 \%$ were students of 200 level at University under study, while the lowest (15) or 3.75\% of respondents were postgraduate students of the university under the study.

Table 5: Means of accessing Social Media by Muslim Students under the study

\begin{tabular}{|c|c|c|}
\hline $\begin{array}{c}\text { Means of accessing Social } \\
\text { Media }\end{array}$ & Frequency & Percentage (\%) \\
\hline Laptop & 17 & 4.25 \\
\hline iPad & 18 & 4.50 \\
\hline Smart Phone & 186 & 46.50 \\
\hline Ordinary Phone & 12 & 3.00 \\
\hline Laptop/ Smart Phone & 42 & 10.50 \\
\hline iPad/ Smart Phone & 18 & 4.50 \\
\hline Smart Phone/ Ordinary Phone & 65 & 16.25 \\
\hline Laptop/ Ordinary Phone & 42 & 10.50 \\
\hline Total & $\mathbf{4 0 0}$ & $\mathbf{1 0 0}$ \\
\hline
\end{tabular}

Source: Field Survey 2016.

The above table shows that (17) or $4.25 \%$ of the respondents owned Laptop while (18) or $4.50 \%$ of the students uses iPad. (186) or $46.50 \%$ of the respondents had smart phone while (12) or $3.00 \%$ uses ordinary phone. (42) $10.50 \%$ of the students are using Laptop/ smart phone while 
(18) or $4.50 \%$ of the respondents owned iPad/ smart phone. (65) or $16.25 \%$ uses smart phone/ ordinary phone while $(42)$ or $10.50 \%$ of the students are using Laptop/ ordinary phone. This indicates that the most commonly used communicating device by students under study is the smart phone while laptop is the least use device. This could be attributed to the growing awareness about social media among students.

Table 6: Usage of Specific Social Media by Muslim Students

\begin{tabular}{|c|c|c|}
\hline Response & Frequency & Percentage (\%) \\
\hline WhatsApp & 311 & 25.45 \\
\hline Facebook & 272 & 22.25 \\
\hline BB Chat & 35 & 2.86 \\
\hline Twitter & 151 & 12.35 \\
\hline MySpace & 40 & 3.27 \\
\hline You Tube & 48 & 3.93 \\
\hline Salamworld & 61 & 4.99 \\
\hline Viber & 65 & 5.32 \\
\hline Imo & 18 & 1.47 \\
\hline Ummaland & 46 & 3.76 \\
\hline We Chat & 76 & 6.22 \\
\hline Badoo & 19 & 1.55 \\
\hline Muslim Social & 80 & 6.55 \\
\hline Total & 1222 & 99.97 \\
\hline
\end{tabular}

Source: Field Survey 2016.

Note: The total frequency is more than the total number of respondents because the respondents were asked to tick as many options as appropriates.

From the table, above it can be observed that (311) or $25.45 \%$ the respondents know how to manipulate WhatsApp while (272) or $22.25 \%$ of the students knows how to use Facebook. (35) or $2.86 \%$ do navigate BB Chat while (151) or $12.35 \%$ uses Twitter. (40) or $3.27 \%$ have account in MySpace and (48) or 3.93\% can manipulate You Tube. (61) or 4.99\% of the respondents have experience on Salamworld while (65) or 5.32\% of the students uses Viber. (18) $1.47 \%$ uses imo while (46) or $3.76 \%$ the respondents know how to use Ummaland, (76) or $6.22 \%$ uses We Chat. (19) or $1.55 \%$ of the respondents navigate through Badoo and (80) or $6.55 \%$ the students know how to surf Muslim Social. This indicates that majority of the Muslim students frequently connect to WhatsApp and Facebook while the least social media sites connect by the students is imo with 18 or $1.47 \%$.

Table 7: Reason for connecting to Social Media by Muslim Students

\begin{tabular}{|c|c|c|}
\hline Response & Frequency & Percentage (\%) \\
\hline Chatting & 44 & 11.00 \\
\hline Sports and World News & 55 & 13.75 \\
\hline Da'wah & 59 & 14.75 \\
\hline Entertainment & 27 & 6.75 \\
\hline Learning Materials & 24 & 6.00 \\
\hline Chatting, Da'wah and World News & 124 & 31.00 \\
\hline Entertainment and Da'wah & 67 & 16.75 \\
\hline Total & 400 & 100 \\
\hline
\end{tabular}

Source: Field Survey 2016.

Page | 36 
The above table shows that (44) or $11.00 \%$ of the respondents connect to social media for the purpose of chatting while (55) or $13.75 \%$ navigate it for Sports and World News. (59) or $14.75 \%$ of the respondents do connect to social media for Da'wah while (27) or 6.75\% connect to social media for entertainments. (24) or $6.00 \%$ do navigate the social media for learning material. (124) or $31.00 \%$ for chatting, Da'wah and World News while (67) or $16.75 \%$ do it for entertainment and Da'wah. This implies the most important reasons for connecting to social media by the group under study were learning new things or ideas, making Da'wah and the sharing of information.

Table 8: Level of checking Social Media account in a day

\begin{tabular}{|c|c|c|}
\hline Level of checking Social media account & Frequency & Percentage (\%) \\
\hline Once in a day & 31 & 7.75 \\
\hline $2-5$ times in a day & 110 & 27.50 \\
\hline 6-10 in a day & 98 & 24.50 \\
\hline Above 10 times in a day & 161 & 40.25 \\
\hline Total & 400 & 100 \\
\hline
\end{tabular}

Source: Field Survey 2016.

The above table shows that 31 or $(7.75 \%)$ check their social media account once in a day while 110 or $(27.50 \%)$ login to their account 2 - 5 times in a day. 98 or $(24.50 \%)$ browse their social media $6-10$ times in a day while 161 or $(40.25 \%)$ attempt their social media account above 10 times in a day. This indicates that majority of the students' check their account more than ten times in a day while 31, the least number of the students check their account is once in a day.

Table 9: The Social Media sites that spread Islam according to the Muslim Students under the study

\begin{tabular}{|l|c|c|}
\hline \multicolumn{1}{|c|}{ Response } & Frequency & Percentage (\%) \\
\hline Tutlub and Facebook & 30 & 7.50 \\
\hline Ummaland & 46 & 11.50 \\
\hline Facebook and MuslimSocial & 65 & 16.25 \\
\hline Ummaland and WhatsApp & 22 & 5.50 \\
\hline youTube and Tutlub & 15 & 3.75 \\
\hline Twitter and YouTube & 21 & 5.25 \\
\hline Qur'anEdu and Facebook & 24 & 6.00 \\
\hline Finding Muslims and Facebook & 31 & 7.75 \\
\hline Salamworld and Ummaland & 17 & 4.25 \\
\hline WhatsApp, Facebook, Twitter and Tutlub & 31 & 7.75 \\
\hline Qur'anEdu and YouTube & 62 & 15.50 \\
\hline SalamYou, Facebook and Ummaland & 36 & 9.00 \\
\hline Total & 400 & 100 \\
\hline
\end{tabular}

Source: Field Survey 2016.

The above table shows that (30) or $7.50 \%$ of the respondents indicated that Tutlub/ Facebook are use in the spread of Islam. (46) or 11.50\% indicated Ummaland as the social media site that can be used in the spraed of Islam. (65) or $16.25 \%$ of the respondents indicated Facebook/ MuslimSocial. (22) or 5.50\% indicated that Ummaland/ WhatsApp are used in the 
spread of Islam. (15) or 3.75\% indicated You Tube / Tutlub while (21) or 5.25\% of the respondents indicated Twitter/ You Tube. (24) or $6.00 \%$ of the respondents indicated Qur'anEdu/ Facebook while (31) or 7.75\% indicated Finding Muslims/ Facebook. (17) or $4.25 \%$ of the respondents indicated Salamworld/ Ummaland while (31) $7.75 \%$ indicated WhatsApp, Facebook, Tutlub and Twitter. (62) or $15.50 \%$ of the respondents indicated Qur'anEdu/ You Tube as social media sites that spread the teachings of Islam. (36) or $9.00 \%$ of the respondents indicated SalamYou, Facebook and Ummaland. This shows that majority of the students under study are aware that Facebook, WhatsApp, You Tube, Tutlub and Ummaland as social media sites that spread the teachings of Islam while Finding Muslims, MuslimSocial and Twitter were the least means of spreading Islam according to the students.

Table 10: The Positive Effects of Social Media according to Muslim Students

\begin{tabular}{|c|c|c|}
\hline The Positive effects of Social Media & Frequency & Percentage (\%) \\
\hline It serves as source of information and communication. & 50 & 12.50 \\
\hline Source of interaction between friends and family. & 62 & 15.50 \\
\hline Means of awareness and advertisement. & 43 & 10.75 \\
\hline It enhances learning and education. & 33 & 8.25 \\
\hline It allows interaction with people from various parts of the world. & 18 & 4.50 \\
\hline It removes all communication and interaction barriers (Reduces & 45 & 11.25 \\
\hline communication barriers). & 28 & 7.00 \\
\hline It unites people and makes people to maintain cordial relationship. & 41 & 10.25 \\
\hline It encourages socialization. & 35 & 8.75 \\
\hline Access to research. & 45 & 11.25 \\
\hline Tt makes the spread of Islamic teachings faster and easier. & 400 & 100 \\
\hline
\end{tabular}

Source: Field Survey 2016.

Meanwhile, table 10 shows that 50 or $(12.50 \%)$ of the respondents suggested that one of the positive effects of social media is that, it serves as source of information and communication, 62 or $(15.50 \%)$ see it as a source of interaction between friends and family while 43 or $(10.75 \%)$ say it is a means of awareness and advertisement. 33 or $(8.25 \%)$ of the respondents opined that, it enhances learning and education. 18 or $(4.50 \%)$ indicated that it allows interaction with people from various parts of the world while 45 or $(11.25 \%)$ are of the view that it removes all communication and interaction barriers (Reduces communication barriers), 28 or $(7.00 \%)$ indicated that it unites people and make people to maintain cordial relationship, 41 or $(10.25 \%)$ indicated that it encourages socialization while 35 or $(8.75 \%)$ indicated that it facilitates access to research. While 45 or (11.25\%) indicated that it makes the spread of Islamic teachings faster and easier. The highest of number of students 62 or $15.50 \%$ indicate source of interaction between friends and family as the positive effects of social media, while 18 or $4.50 \%$ indicates that it allows interaction with people from various parts of the world. 
Table 11: The Negative Effects of Social Media according to Muslim Students

\begin{tabular}{|c|c|c|}
\hline Negative effects of Social Media & Frequency & Percentage $(\%)$ \\
\hline It encourages people to be more public about their personal lives. & 15 & 3.75 \\
\hline Encourages poor grammar, usage, and spelling of language. & 21 & 5.25 \\
\hline Allowing the spread of false/ misinformation. & 17 & 4.25 \\
\hline Creates a culture in which students spread racy pictures. & 25 & 6.25 \\
\hline $\begin{array}{l}\text { Students post poorly thought out comments which cause irreparable harm to } \\
\text { one's reputation. }\end{array}$ & 18 & 4.50 \\
\hline It creates a platform for cyber bullying. & 28 & 7.00 \\
\hline Reduces learning and research capabilities. & 21 & 5.25 \\
\hline Time wastage & 33 & 8.25 \\
\hline Reduction in real human contact. & 14 & 3.50 \\
\hline Lack of interpersonal skills. & 11 & 2.75 \\
\hline Online grooming. & 24 & 6.00 \\
\hline Hate/ unguarded speech & 36 & 9.00 \\
\hline Exposure to pornographic images/ films and cyber crime & 14 & 3.50 \\
\hline Promotion of indecent dressing & 38 & 9.50 \\
\hline It leads to lateness/ abstinence from the performance of Salat. & 17 & 4.25 \\
\hline Distortion of facts about Islam & 29 & 7.25 \\
\hline Un- Islamic dating, chatting and gambling. & 39 & 9.75 \\
\hline Total & 400 & 100 \\
\hline
\end{tabular}

Source: Field Survey 2016.

From table 11, it can be seen that 15 or $(3.75 \%)$ of the respondents indicated that one of the negative effects of social media is that it encourages people to be more public about their personal lives. 21 or $(5.25 \%)$ indicated that it encourages poor grammar, usage, and spelling of language while 17 or $(4.25 \%)$ said it allows the spread of falsehood/ misinformation. 25 or $(6.25 \%)$ indicated that it creates a culture in which students spread racy pictures, 18 or $(4.50 \%)$ indicated that Students post poorly thought out comments which causes irreparable harm to one's reputation while 28 or $(7.00 \%)$ indicated that it creates a platform for cyber bullying. 21 or $(5.25 \%)$ indicated that it reduces learning and research capabilities, 33 or $(8.25 \%)$ opined that it time wasting, 14 or $(3.50 \%)$ indicated that it reduces real human contact while 11 or $(2.75 \%)$ indicated that it leads to lack of interpersonal skills. 24 or $(6.00 \%)$ of the respondents show that it leads to online grooming, 36 or $(9.00 \%)$ indicated that it leads to hate/ unguarded speech while 14 or $(3.50 \%)$ indicated that it exposes students to pornographic images/ films and cyber-crime. 38 or $(9.50 \%)$ indicated that it promotes indecent dressing among the group members. 17 or $(4.25 \%)$ indicated that it leads to lateness/ abstinence from the performance of Salat (prayer), 29 or $(7.25 \%)$ indicated that it leads to distortion of facts about Islam while 39 or $(9.75 \%)$ of the respondents indicated that it leads to Un-Islamic dating, chatting and gambling. The table shows that the highest number of respondent 29 or $9.75 \%$ indicate Un- Islamic dating, chatting and gambling as negative effects of social media while least number of respondents 11 or $2.75 \%$ indicate lack of interpersonal skills as one of the negative effects of social media. 
Table 12: How to utilize Social Media to spread Islam by Muslim Students

\begin{tabular}{|l|c|c|}
\hline \multicolumn{1}{|c|}{ How to utilize Social Media sites } & Frequency & Percentage (\%) \\
\hline Creating $D a^{\prime}$ wah group. & 83 & 20.75 \\
\hline Posting and sharing the message of Islam. & 86 & 21.50 \\
\hline Discussing issues related with Islam during chatting & 47 & 11.75 \\
\hline Spreading Islamic knowledge on Facebook and WhatsApp. & 52 & 13.00 \\
\hline Posting the character and manners of the Prophet Muhammad (S.A.W). & 13 & 3.25 \\
\hline Calling people to the true teachings of Islam. & 26 & 6.50 \\
\hline Posting and sharing the contents of the Qur'an and Hadith & 51 & 12.75 \\
\hline Protecting the image of Islam and Muslims on social media. & 42 & 10.50 \\
\hline Total & 400 & 100 \\
\hline
\end{tabular}

Source: Field Survey 2016.

The above table shows that 83 or $(20.75 \%)$ of the respondents indicated that creating Da'wah group is one the ways to use social media to spread Islam. 86 or $(21.50 \%)$ indicated that posting and sharing the message of Islam is another means while 47 or $(11.75 \%)$ indicated discussing issues related with Islam during chatting. 52 or $(13.00 \%)$ indicated that one of the ways to spread Islam is by sharing Islamic knowledge on social media platforms, 13 or $(3.25 \%)$ indicated posting the character and manners of the Prophet Muhammad (S.A.W) while 26 or $(6.50 \%)$ calling people to the true teachings of Islam. 51 or $(12.75 \%)$ show that posting and sharing the contents of the Qur'an and Hadith is another way of spreading Islam through social media, 42 or $(10.50 \%)$ indicated that one of the ways to use social media to spread Islam is by protecting the image of Islam and Muslims on social media. The highest number 86 or $21.50 \%$ of the respondents suggest that posting and sharing the message of Islam is one of the way to spread Islam by Muslim students while the lowest number 13 or $3.25 \%$ of the respondents suggest that posting the character and manners of the Prophet Muhammad (S.A.W) is one of the way to spread Islam by Muslim students.

Table 13: Ways to avoid the Negative Effects of Social Media according to the Muslim Students

\begin{tabular}{|l|c|c|}
\hline \multicolumn{1}{|c|}{ Ways to avoid negative effects of Social Media } & Frequency & Percentage (\%) \\
\hline Desist from visiting pornographic sites. & 72 & 18.00 \\
\hline Reduce the length of time spent online chatting. & 22 & 5.50 \\
\hline Visit sites that spread true teachings of Islam. & 41 & 10.25 \\
\hline Visit sites that are beneficial to your area of study. & 45 & 11.25 \\
\hline Avoiding online betting and gambling sites. & 34 & 8.50 \\
\hline Avoid sites that spread rumour and false stories. & 51 & 12.75 \\
\hline Desist from posting pictures of nudity and pornographic videos. & 50 & 12.50 \\
\hline Do not subscribe to pages that are against Islam. & 37 & 9.25 \\
\hline Be mindful of the language used when making comments or posts. & 48 & 12.00 \\
\hline Total & 400 & 100 \\
\hline
\end{tabular}

Source: Field Survey 2016

From the table, above, it can be observed that 72 or $(18.00 \%)$ of the respondents indicated that one of the ways to avoid the negative effects of social media is that students should desist from visiting pornographic sites. While 22 or $(5.50 \%)$ agreed that Muslim students should reduce Page | 40 
the length of time spent online chatting. But 41 or $(10.25 \%)$ of respondents went for visiting sites that spread true teachings of Islam. 45 or $(11.25 \%)$ indicated that visiting sites that are beneficial to your area of study would avoid the negative effects of social media. 34 or $(8.50 \%)$ of the respondents indicated avoiding online betting and gambling sites while 51 or $(12.75 \%)$ indicated that Muslim students should avoid sites that spread rumor and false stories. 50 or $(12.50 \%)$ suggested that students should desist from posting pictures of nudity and pornographic videos, 37 or $(9.25 \%)$ indicated that students should not subscribe to pages that are against Islam while 48 or $(12.00 \%)$ indicated that Muslim students should be mindful of the language used when making comments or posts. The highest number 72 or $18.00 \%$ of the respondents suggest that, to desist from visiting pornographic sites is one of the way to avoid the negative effects of social media, while the lowest number 22 or $5.50 \%$ of the respondents suggest reduction of the length of time spent online chatting as a way to avoid the negative effects of social media This suggests that if these ways are utilized students under study can avoid the negative effects of social media.

\subsection{Discussion of Major Findings}

In this section, findings of the data collected from field survey will be discussed. The study assessed the utilization of social media platforms by Muslim students in Nasarawa State University, Keffi, Nigeria.

This paper found out that the proper and appropriate use of social media among Muslim student has helped significantly in the spread of Islam on Campus of the Nasarawa State University. It has provided an avenue for engaging large virtual audience without the constraints of money, time and space. This is vindicated by the findings of Abubakar (2011). The study concluded that social media have the capacity of boosting participation because of their open conversational nature, connectedness and textual and audio-visual characteristic appeal.

The study also found that there are some negative effects that accompanied the usage of social media among Muslim students. Most of the students that spent large part of their time on social media instead of studies and other Islamic obligations tend to perform poorly in their academic activities. This is corroborated by the findings of Paul and Karpinski, (2009) where it was found that excessive use of internet and particularly Facebook by students extraverted personalities escort towards poor academic performance.

On the utilization of the social media by Muslim students, the study revealed that Muslim student used most of the social media sites in the creation of Da'awah group, posting and sharing of the messages of Islam. In relation with the findings, Salman (n.d) viewed that in the past, seeking knowledge about Islam was mainly restricted to the Masjids, educational institutions, and learning from imams and sheikhs. These traditional learning opportunities remain intact. However, now Muslims are also able to learn, question, teach, and network through social media sites. There are more avenues through which to learn about Islam. The Internet has given the public access to all kinds of information and made Islamic literature so much more accessible. On YouTube, for example, you can listen to a lecture in any language you want and whenever you want.

Findings from the study revealed that majority of the respondents are male students. It further portrayed that among the social media sites, large proportion of the Muslim students sampled used Whatapp followed by Facebook. This correlates with the findings of Gehad, Mahdi and Azizah, 2012 and Mohammed and Abubakar, 2017). The study found out that many 
of the Social Media like Facebook, provide platform for Muslim Students in sharing permissible components of data with their fellow Muslims friend and relatives.

\subsection{CONCLUSION}

The concept of social media is part of the growing trends of modern technology in the present world whereby this research has examined the purpose and use of social media by Muslim students. The open platform provided by social media, the open discussions that can occur and the ability for content to be created by the people seem like factors which can benefit the objective of the propagation of Islam. So far, this research work has highlighted the effects of social media among Muslim students. It also discussed the benefits which these social media sites offer, which include the enhancement of work efficiency, propagation of the true teachings of Islam, maintenance of social bond, source of information and so on. However, a greater attention was given to the moral implication of the abuse of these social media sites especially by the Muslim students in Nasarawa State University, Keffi. Findings also indicated that most of the students are influenced to a great extent by the social media negatively because their attention are carried away by chatting, music, sexual promiscuity, internet crime, indecent dressing, pornographic images/ videos and sexual harassment, loss of sense of sacredness of human life and neighbourliness and impatience and quick syndrome of making money while forgetting their Ibadat (worshipping of Allah) and their academic activities are neglected.

Notwithstanding these immoral effects of social media in Nasarawa State University, Keffi, one can no longer imagine a world without it. Therefore, all hands must be on deck especially that of management of the institution, parents and students themselves, to salvage the social media-induced moral degeneration that is currently being witnessed. It can be concluded that, Muslim students mainly use social media to socialize on-line with their friends. The research also found out that the use of social media by Muslim students, to some extent, contributes to the understanding of their religion. However, this largely depends on how they use it and how they perceive the Islamic information shared on social networking sites. From the research findings, there is also evidence that social media has contributed to some extent in the understanding of the religion Islam among Muslim students.

\subsection{Recommendations}

Based on the findings and conclusions of this study, the following recommendations are made:

i. There should be policy for social media use that must be made mandatory for every higher institution learning and must be implemented.

ii. Higher institutions of learning should educate the academic communities on the potentials of social media and the best ways of using them.

iii. Islamic centres, institutes and organizations should also develop and sustain ways of using social media to propagate Islam and Islamic teachings.

iv. Muslim students should also emphasise to one another the importance of creating Da'wah groups on social media platforms for effective propagation of the true teachings of Islam. 
v. Software developers should develop software that could be used to control social media usage in the campus so that students will not lose their primary aim of being in the higher institution of learning.

vi. There should be awareness programmes in schools and universities that address the students synthesize on the pros and cons for using social media sites.

vii. Conferences and seminars should be arranged that address the best means and technological actions/ mechanisms to overcome or reduce the negative aspects of using social media sites in the Nigerian universities and Nigeria at large.

viii. The students should create a balance between chit-chatting and academic activities. More attention should be directed to research.

ix. Students should also avoid the obsession and abuse of the social media sites, but instead should moderately utilize the array of benefits which they offer.

x. The government should prepare a censorship policy to stop the entering of immoral contents into social media sites, a porn sites are available easily in Nigeria for students because of lack of check from government. Therefore, there should be some strict policy regarding the access to such sites.

\section{References}

Abubakar, Abdulmutallib Ado. (2011). "Political Participation in Social Media during the 2011 Presidential Electioneering" in Oladokun Omojola et al (eds.) Media, Terrorism and Political Communication in a Multi-Cultural Environment: ACCE Conference Proceedings. Ota (Nigeria): ACCE Loc. Pp. 445-453.

Ahmad, S. (2011). YouTube usage and behaviour change among Nigerian university students. Journal of education and sociology, Vol.4 (2), pp. 32-42

Ajewole Olaniyi Olowu, and Fasola Omobolanle Seri. (2012). "A Study of Social Network Addiction among Youths in Nigeria" Journal of Social Science and Policy Review 2, Volume 4, pp. 64-71.

Buhari, Sanusi Rufai, Gambo Ibrahim Ahmad, Bashir HadiAshara. (2014). "Use of Social Media among Students of Nigerian Polytechnic" International Conference on Communication, Media Technology and Design, Istanbul, Turkey, 24- 26 April. Pp. 302-305.

Busha H. Charles. (1978). Method for Social Science Research, Macmillan, New York.

Englander F, Terregrossa, R.A. Wang, Z. (2010). Facebook and Myspace Generation cannot form relationships. Educational Review, 62(1). Pp. 85- 96. http://www.telegraph.co.uk/technology/3357741//Facebookand-MySpace-generationcannot-form relationships.html. Retrieved on 13/02/2016.

Gehad Mohammed Sharaf, Mahdi Alhaji Musa, Azizah Abdul Rahman. (2012). An Examination of Social Networking Sites Usage among Muslim Students in Islamic Perspectives. International Journal of Engineering and Advance Technology (IJEAT), Vol. -1 Issue-4. Pp. 273-278.

Greg H. Ezeah, Chika Euphemia Asogwa and Edogor, Ignatius Obiorah. (2013). Social Media Use among Students of Universities in South-East Nigeria. IOSR Journal of Humanities and Social Science (IOSR-JHSS) Volume 16, Issue 3. Pp. 23-32.

Idankwo Lami. (2011). The use of Social Media among Nigerian Youths. www.slideshare.net/goldlami/the-useof-socialmedia-networks-among-nigerianyouths. Retrieved 10/02/2016.

Ishfaq Ahmad and Tehmina faiz Qazi. (2011). A look out for academic costs of SNSs, A Student based perspective. African journal of business management, 51(12), 5022-5031.

Page $\mid 43$ 
Junco, Reynol. (2012). Too Much Face and not Enough Books: The Relationship between Multiple indices of Facebook use and Academic Performance. Computers \& Education, Vol.58. PP. 1-11. doi:10.1016/j.chb.2011.08.026.

Khan Urmee. (2009). Facebook Students Underachieve in Exams. Daily Telegraph, www.telegraph.co.uk/education/educationnews/5145243/Facebook-students-underachieve-inexams.html. Retrieved on 23/02/2016

Muhamad Zaki Mustafa, Zulkiple Abd. Ghani, Abdul Rahim Zumrah, Roslizawati Mohd Ramly, Wan Mohd Fazrul Azdi and Zainol Abidin Ahmad. (2013). "Facebook as Social Media Tools among Muslim Youths in Malaysia.” American International Journal of Social Science, Vol. 2 No. 8. Pp. 173-177.

Muhammad, M.S, and Abubakar, S. (2017). An Investigation of the Social Media Platforms Utilization among Muslim Students. A Paper Presented at the National Conference on Religion and Pugnacity Organised by Nigerian University Scholars in Religions (NUSREL) Held on 21st - 24 April 2017 at Al-Hikmah University Ilorin, Kwara State.

Nalwa K, and Anand A.P. (2003). Facebook Fixation Harms Student Grades. Cyber Psychology Behavior. 6(6). Pp. 653-656. doi:10.1089/109493103322725441.

Ogedebe, P. M., Emmanuel, J. A., \& Musa, Y. (2012). A survey on Facebook and Academic Performance in Nigeria Universities. International Journal of Engineering Research and Applications (IJERA) Vol. 2, Issue 4. Pp. 788-797.

Oluwatoyin A. Enikuomehin. (2011). "ICT, CGPA: Consequences of Social Networks In An Internet Driven Learning Society.” International Journal of Computer Trends and Technology, Vol 2, Issue 2. Pp. 9-14.

Onyeka Ndidi Camilia, Sajoh Dahiru Ibrahim \& Bulus Lucy Dalhatu. (2013). The Effect of Social Networking Sites Usage on the Studies of Nigerian Students. The International Journal of Engineering and Science (IJES) Volume, 2 Issue 7, Pp. 39-46.

Paul A. Kirschner and Aryn C. Karpinski. (2010). Facebook and Academic Performance. Computers in Human Behavior, 26. Pp.1237-1245.

Robert Gill. (2013). The use of Social Media for Constructive Discussion in an Academic Events Management Unit: An Australian Practice-Based Case Study. European Journal of Academic Research, Vol. 1, Issue 1. www.journalsgate.com. Retrieved on 20/03/2016.

Salman Javeria. (nd.). Impact of Media and Social Media on Islam and Muslims. Retrieved from islamicstudies.islammessage.com/ResearchPapers.aspx. Retrieved on 14/02/2016.

Sana Rouis, Moez Limayem and Esmail Salehi-Sangari. (2011). Impacts of Facebook usage on Students' Academic achievements. Electronic Journal of Research in Educational Psychology (EJREP), 9(3), No. 25. Pp. 961-994.

Tiffany A. Pempek, Yevdokiya A. Yermolayeva, Sandra L. Calvert. (2009). "College Students Social Networking Experience on Facebook." Journal of Applied Developmental Psychology. 30(3). PP. $227-238$. 